\section{The Pursuit of Flexibility in the New Zealand Supermarket: The Employment Contracts Act, Continuities and Discontinuities}

\section{Alistair Pringle*}

This article offers a perspective on the growing debate on the future direction of industrial relations in New Zealand. It argues the existence of a significant relationship between the business environment of an industry and the industrial relations practices adopted by its constituent employers. In focusing on the pursuit of internal labour market flexibility in the retail food industry it attempts to analyse the various factors that have both impelled and impeded this process. It concludes that while the demand for greater flexibility tends to be generated within the industry, its successful implementation is frequently subject to external factors.

\section{Introduction}

The most obvious consequence of the virtual disappearance of multi-employer bargainin and awards (Harbridge, 1993) since the advent of the Employment Contracts Act (the Act) is the emergence of a range of bargaining outcomes and employer behaviours and practices, based on single employer bargaining and enterprise-based contracts (Armitage and Dunbar, 1993; Boxall, 1993; Department of Labour, 1993; Harbridge, 1992; Harbridge, 1993). At first sight this might appear to suggest that the Act has been as successful as its proponents claim it has in providing for the "diversity of New Zealand enterprises" (Birch, 1991); and that the peculiar characteristics of individual enterprises, hitherto subsumed in the "universal" outcomes of centralised bargaining, now play an increasingly part in the determination of wages and conditions.

However, as Ryan's (1992) research suggests, the issue of workplace flexibility is not on which should, or can, be reduced to generalisations. Organisations do not operate in vacuum and the success of individual attempts to introduce variations in "the modu operandi of managing labour" (Littler, 1990) must eventually be measured against the achievements of other employers in the same industry (Child 1969). Thus, notwithstanding that recent contract analysis confirms that the goal of cost reduction and containment

Tutor and Doctoral student, Department of Political Science, University of Canterbury.

The article is based on the author's current research. The financial assistance of an Industrial Relations Scholarship from the New Zealand Institute of Industrial Relations Research Inc. is gratefully acknowledged.
My thanks are also due to Dr Terry Austrin for his invaluable advice in the preparation of the article, to the anonymous Journal referees for their constructive comments and to those managers, employees and unio officials involved in the retail food industry, who willingly gave of their time and experience.
(Enderwick, 1992; Harbridge, 1992) is a high priority across all industries, the patterns of flexibility sought by different enterprises within an industry are likely to be influenced as much by the economic environment of the industry as by their own goals and strategies.

The current debate over the effect of the Act on the future pattern of industrial relations in Thew Zealand might well be enhanced therefore by the inclusion of analysis of the relationship between changes in the business environments of different industries and the relationship between changes in the business environments of different industries and the
industrial relations practices adopted by different employers within them. Such analysis should extend to include interventions by the state, as well as the logic of structural and technological change and the influence of changing patterns of economic development within the industry in question.

In following these themes, this article proposes to examine developments in internal labour market flexibility in the retail food industry in New Zealand; an industry whose employers have become significant actors in the post-Act environment, despite indications of an initial lack of enthusiasm for the legislation (McAndrew and Hursthouse, 1991). Indeed, one major employer is on record as having described it as "having the potential for a labour relations shambles" (Herbert, 1991) ${ }^{1}$.

The time frame for the analysis will incorporate the period of major structural and infrastructural change that, broadly speaking, began with the introduction of the Shop Trading Hours Act in 1977 and concludes in late 1993, with the consolidation of the second round of contracts concluded under the Act. The focus of study is on the enterprise rather than the individual workplace; a deliberate choice, influenced by the concentration of ownership and the consequent high degree of centralised control and integration that characterises the industry in New Zealand.

The analysis itself focuses on crucial aspects of change in three specific areas: the expansion of corporate investment and the concentration of ownership; the linkages between the entry of retail capital, deregulation, and the development of internal labour market flexibility as a key strategic tool in the search for competitive edge; finally, the impact of the Employment Contracts Act on established patterns of work and contractual arrangements. The article concludes with a brief discussion of future trends in bargaining processes and worker organisation in the industry.

The lack of direct access to contract negotiations and contract documents was a critical factor in the choice of methodology, which comprises a fusion of qualitative and quantitative research. Primary research was conducted through a combination of informal discussion and semi-structured interviews with a broad cross-section of employers, employees and union officials operating in the industry. This material was supplemented by the examination of documents made available by individual employers, together with industry and business publications, academic journals and research articles - from inside and outside New Zealand - as well as Government statistics. The triangulation of these methods

Similar reservations and an endorsement of the stability of the existing system of collective bargaining were given by a senior manager of the Foodstuffs group, during an interview held around the same time. 
proved to be invaluable, not only in checking the accuracy of interview material, but also in uncovering additional information.

\section{Competition and concentration}

The chief attraction of food retailing for retail capital lies in its consistent returns. Unlike most other forms of retailing it is not subject to seasonal variations in demand and generates a cash flow that is not only strong, but steady throughout the year. The Australian operations of the Coles supermarket chain, for example, reportedly produce an average of A $\$ 19$ million each trading day (Barner, 1992). Although on a smaller scale, New Zealand's national grocery bill of around $\$ 4$ billion plus annually still represents a lucrative inducement to investment, particularly during a period of international recession and capital restructuring.

However, the considerable capital outlay involved in the establishment and operation of a large modern supermarket, ${ }^{2}$ in an industry notorious for its low profit margins - commonly in the range 1.5 percent to 4 percent (Barner, 1992) - requires that a high turnover is essential to maintain the economic viability of the investment. This, in turn, generates intense competition among companies for an increasing share of the consumer market.

A common competitive strategy developed in the large retail food markets in Australia, the United Kingdom and Europe is that of "segmentation" or "niche" marketing, in which individual companies attempt to capitalise on the tastes and preferences of a particular segment of the population, (Lewis and Thomas, 1990; Marchington and Harrison, 1991; Marchington and Parker 1990)

Evidence of a similar strategy, diverging along the "psychographic fissures" between choice, quality and low price can be seen in the trading patterns of the industry in New Zealand during the early 1980s (Chapple, 1988). In New Zealand's relatively small and scattered market, this "single format" strategy soon gave way to a "two-format" one, with each major chain seeking to cover the field by offering the public a choice of a price-driven or a rangedriven outlet. As a consequence, the late 1980s and the early 1990s saw an increase in mergers, takeovers and rationalisation as the major industry chains sought to establish national networks at both the top and bottom ends of the market.

The increase in direct competition produced by this integration, coming as it did at a time of renewed recession, significantly reduced the market share of the "full-service" superstores, such as Progressive's Foodtown chain (Williams, 1993). The drawcards of service, quality and freshness consequently gave way to two more fundamental inducements, low prices and convenient shopping hours.

2 Barner notes that as much as 50 percent of the asset base is taken up with the creation of a technologically efficient and attractive shopping environment, with a further 40 percent tied up in stock.
Apart from the multiplicity of family owned and operated convenience stores and corner dairies that still cling tenaciously to a modest share of the market, the industry is now substantially grouped into one or the other of two distinct formats. The traditional neighbourhood supermarket, such as Foodstuffs' New World and Four Square, Progressive's Supervalue and Franklin's Woolworths stores continues to form a solid core within the industry, holding in the vicinity of 53 percent of the market. However their full-service style, combined with a generally lower volume of sales and lower turnover, makes them vulnerable to competition from the larger discount stores and maximarts.

As noted, the industry's most rapid growth has been in the discount store sector, dominated by the price-driven, labour intensive, high running cost "food barn" operations, the "flagships" of the industry, Foodtown, Three Guys, Countdown, Big Fresh and Pak'n Save. This sector now accounts for about 40 percent of the market and has become the focal point of corporate competition.

\section{The industry: concentration and infrastructures}

This transformation of the retail food industry in New Zealand from an indigenous industry, dominated by privately owned and operated grocery stores trading under the banners of various co-operatively owned wholesale groups (Foodstuffs, Grocers United Stores (GUS), Independent Grocers Association (IGA)), to one dominated by corporate investment, exemplifies a common aspect of contemporary retail restructuring. This "transmogrification of petit bourgeois firms into capitalist firms" (Ducatel and Blomley, 1990), which effectively began with Magnum Corporation's purchase of the Countdown and Rattrays roups (both subsequently sold to Foodland Associated Ltd) in the mid-1980s, has seen a substantial part of the industry pass into the hands of international owners and its concentration into the control of three nationwide conglomerates (Table 1).

Of these, two are wholly owned or controlled subsidiaries of major trans-Tasman and international companies. The larger, in terms of its share of the market, estimated at approximately 32 percent, is the Australian owned Progressive Enterprises group. Progressive, a former Coles Meyer subsidiary, has recently come under the control of West Australian wholesale grocery distributor, Foodland Associated Ltd. The merger of these operations has brought together under the one ownership umbrella, the Countdown chain previously operated by Foodland's New Zealand subsidiary, FAL NZ and Progressive's own Foodtown and Three Guys chains. The same merger has also resulted in Progressive acquiring the former FAL NZ owned Rattrays group, which includes the wholesale operation of Rattrays and the former GUS stores trading under the Supervalue, Dollarwise, Pricecutter, IGA and Super 7 banners.

The second overseas owned operator is the Bermuda registered, Hong Kong based Dairy Farm International, a jointly owned subsidiary of Jardine Matheson and the Hong Kong and Shanghai Bank. This international food retailing and manufacturing group also operates supermarkets in South East Asia, Spain and the United Kingdom. Through its Australian subsidiary Franklins, Dairy Farm operates the Big Fresh, Woolworths and Price Chopper 
chains and is linked to the Safeways chain of convenience stores. Together, this group of stores lay claim to some 17 percent of the New Zealand market.

The remaining 51 percent of New Zealand's retail grocery market is estimated to be shared among the member stores of the New Zealand owned Foodstuffs group: the Pak'n Save, New World and Four Square supermarkets. Although retaining the formal structures of its co-operative origins, Foodstuffs itself is now much more than a retailer owned wholesale facility. It now overshadows its member stores, acting not merely as a wholesale supplier, but as financier, developer and leaseholder; and, increasingly in the larger discoun operations, as part owner of the business. In practice it is now virtually indistinguishable from the other groups.

Table 1:

Food Retailing in New Zealand

Ownership and Market Share (October 1993)

$\begin{gathered}\text { Dairy Farm International } \\ \text { (Bermuda \& Hong Kong) }\end{gathered}$
$\begin{gathered}\text { Franklins Ltd } \\ \text { (Australia) }\end{gathered}$
$\begin{aligned} & \text { Woolworths New Zealand } \\ & (17 \%)\end{aligned}$
$\begin{aligned} & \text { Big Fresh } \\ & \text { Woolworths }\end{aligned}$
$\begin{aligned} & \text { Price Chopper } \\ & \text { Fresh Markets }\end{aligned}$

\section{The pursuit of flexibility: continuity and discontinuity}

The search for new opportunities for the strategic reduction of costs is a constant consideration for retail capital. Within the retail food industry world-wide, as Ducatel and Blomley (1990) have noted, the transfer of "the work of consumption" from retailer to customer, made possible by the development of the self-service supermarket, has also seen the replacement of a once relatively-skilled, male dominated workforce with a low-skilled, female workforce, accompanied by the increasing use of part-time and juvenile workers.

The same trend has been apparent in the pattern of development in the industry within New Zealand. The growing and extensive use of advanced point of sale technology - in which New Zealand is claimed to be a world leader - has taken cost reduction a step further through its capacity for further de-skilling. In addition, supervisory costs have been reduced through the associated ability of the same technology to function as a tool of structural control by monitoring the speed and the error rates of individual checkout operators.

Despite this, food retailing remains a highly labour intensive industry, subject to daily and hourly peaks and troughs in its patterns of labour usage - a factor compounded by the
progressive deregulation of trading hours which took place in New Zealand between 1977 and 1989 (Hince et al., 1990). It is therefore an industry that readily lends itself to the application of the "just-in-time" system to the use of labour, particularly in the large stores which form the main area of competition.

The relaxation of the regulations governing trading hours was not matched by a similar relaxation in the flexibility of the conditions governing the employment of labour. The ability to ensure the presence of the right numbers of staff, in the necessary positions, for the required period of time was denied to employers by the existence of the national "award" system. Based around the 40 hour, five day week and the eight hour day, the main industry award, the New Zealand Retail Grocery and Supermarket Employees Award, together with other awards covering ancillary staff such as clerical workers, bakers and butchers, had established universal and legally enforceable patterns of "normal" working hours and minimum periods of employment. All time worked outside this "normal" span was subject to overtime rates. Thus, while the use of part-time labour, particularly at peaktime and weekends, increased significantly through the $1980 \mathrm{~s}$, rising, according to conservative union estimates, from some 35 percent of the workforce in the mid 1980 s to around 60 percent in the 1990s, the legal right of employers to extend their opening hours remained of limited value while these universal and legally enforceable penal rate provisions remained in force.

Under the pressure of competition some questionable departures from formally negotiated employment practices became evident. Complaints from union sources of a tendency in some industry employers to stretch the award to the limit of its interpretation seemed to be borne out in the conclusions of the Second New Zealand Sweating Commission (1990). The Commission cited extensive instances of what they claimed as de-facto and illegal variations to the award, particularly in the areas of extended hours of work, non-payment 
of penal rates and breaches of the proportions clause restricting the ratio of junior to senior workers.

Nevertheless, despite these pressures, the existence of an overarching legislative and industrial relations framework generally ensured that where change occurred, it was incremental and determined by negotiation between employers and unions rather than unilaterally imposed by management.

By 1990 however, the opening hours of many supermarkets spanned seven days of the week and up to 12 or 15 hours per day. Negotiated concessions in award conditions extending the number of permissible late nights to six in any week, accompanied by smal reductions in minimum overtime payments, were welcomed but, in an increasingly competitive environment, were seen by employers to be too few and too inadequate. Alongside this concern was a growing desire for a more "efficient" system, in which easyto-operate, company-specific documents would replace the multiplicity of awards with their diverse ranges of pay scales and working conditions.

The introduction of the Labour Relations Act 1987, despite its provisions for the negotiation of single enterprise agreements, seems to have provided insufficient incentive for major change. Only one such agreement, the 1990 Woolworths NZ Composite Agreement, was concluded and this constituted little more than an amalgamation of the provisions of two "existing" documents - the Retail Food Award and the Clerical Award - into a single agreement.

A system that had once been praised for its inherent stability was increasingly being perceived as a barrier to much needed flexibility. From having initially viewed the prospect of change to the existing system with some reservation, the industry's employers can now be numbered, if not among the open advocates, at least among the most enthusiastic supporters and significant users of the Employment Contracts Act. ${ }^{3}$

\section{Institutionalising flexibility: contractual arrangements}

One way to the achievement of greater internal efficiencies in the use and overall disposition of the workforce lies through institutionalising the discretionary power of management. Hence, the thrust of employer efforts in contracts negotiated under the Employment Contracts Act has been towards "sectioning off" (Hardy, 1985) previously accessible spheres of influence, so that matters that were previously collectively negotiable become the subject of individual arrangements, or in which management's right to decide is perceived as legitimate and is therefore unchallenged. As noted earlier, a consequence of this process has been the replacement of industry bargaining, with its pluralistic emphasis on the accommodation of opposing interests, by enterprise or workplace negotiation, with its associated connotations of the common interests of labour and capital.

3. This is readily apparent from views that appear in the regular "Store of the Month" feature in "Supermating New Zealond's Premier Grocery Magene". It is particulary marked among the Supervalue and New World stores.
Table 2: Summary of forms of contract covering terms of employment in the retail food industry (as at March 1993)

\begin{tabular}{llll}
\hline Employer & Collective-Individual & Site-Enterprise & Bargaining agent \\
(where applicable
\end{tabular}

Woolworths New Zealand

Big Fresh )

Woolworths )

Price Chopper)

Fresh Markets)

C (2)

E

Union (3)

\begin{tabular}{|c|c|c|c|c|c|}
\hline \\
\hline \multicolumn{6}{|l|}{ Enterprises } \\
\hline 3 Guys & $\mathrm{C}$ & & & $\mathrm{E}$ & Union (3) \\
\hline Foodtown & $\mathrm{C}$ & & & $\mathrm{E}$ & Union (3)n \\
\hline Countdown & $\mathrm{C}$ & & & $\mathrm{E}$ & Union \\
\hline Dollarwise & $\mathrm{C}$ & & $\mathrm{S}$ & & Union \\
\hline Super Value & $\mathrm{C} d$ & $\& \quad \mathrm{I}$ & $\mathrm{S}$ & & Union $(\mathrm{C}$ only) $(3)$ \\
\hline Price Cutter & $\mathrm{C} d$ & $\& \quad I$ & $\mathrm{~S}$ & & \\
\hline Super 7 & & I & $\mathrm{S}$ & & \\
\hline I.G.A. & & I & $\mathrm{S}$ & & \\
\hline \multicolumn{6}{|l|}{ Foodstuffs } \\
\hline$\overline{\text { Pak'N Save }}$ & $\mathrm{C}$ & $\& I(1)$ & $\mathrm{S}$ & & Union $(C$ only $)(3)$ \\
\hline New World & $\mathrm{C}$ & $\& I(1)$ & $\mathrm{S}$ & & Union $(C$ only $)(3)$ \\
\hline Four Square & & I & & & \\
\hline Four Square Discount & & I & & & \\
\hline "On the Spot" & & I & & & \\
\hline
\end{tabular}

$\frac{\text { Notes }}{(1)}$

There are approximately 10 collective contracts, covering 13 stores, all in the North Island. Individual contracts are the norm in all other cases.

(2) One contract covering all enterprises and sites in the group

年 Other contracts provide only for consultation or notification.

Primary Source: "Supermarketing. New Zealand's Premier Grocery Magazine" 1991-1993. 
The range of current contractual arrangements that have superseded the national award are shown in Table 2. In each case the table indicates the nature of the contract, whether collective or individual, enterprise or site-based, and whether or not a bargaining agent is involved.

A full assessment of the reasons for these variations is not possible within the scope of this article. However, recent discussion of pre-Act employer attitudes to centralised bargaining (McAndrew and Hursthouse, 1991; Boxall, 1993) suggests that the inclusion of a brief comparative summary would be helpful, in illustrating the degree to which some of the earlier attitudes of employers in this particular industry towards the Act have now changed.

To this end, it is proposed to follow the typology of industrial relations practices recently proposed by Boxall and Haynes (1992), which depicts elements of both the unitary and pluralistic paradigms in the New Zealand context. In brief, this typology postulates the existence of three broad employer groups. The first includes those who have tended to stay with the traditional pattern of employment relations in the industry; the second, those who have sought to change the pattern through the adoption of alternative techniques, such as Total Quality Management and finally, those who have adopted an overtly anti-union and anti-collective stance.

No single employer in this industry appears to fall in under the first category. The Woolworths NZ group comes closest, having adopted a formula of "modified co-operation" that falls between the first and second categories. Its generally co-operative attitude towards union involvement and its single, wide, union-negotiated collective contract suggest the former, whereas its emphasis on terms such as "team member" instead of "employee" and "team leader" instead of "supervisor" stresses the human resources management technique.

The future place of the Progressive Enterprises group in this typology is more problematic. On the one hand its Foodtown and 3 Guys contracts fall into the first category, tending to suggest a continuing preference for the orderliness of the previous system. The Countdown contract, on the other hand, although nation-wide, collective and union-negotiated, includes a component of employer-assessed, performance based pay, which places it somewhere between the first and second categories. With Countdown stores, Progressive has also inherited an incentive scheme and an in-house, company backed delegate structure, comprised of internally elected "employee representatives", whose role and functions closely parallel those of union delegates. Finally, Progressive's other subsidiary, the Supervalue group of stores, is characterised by a generally anti-union attitude and a predilection towards individual rather than collective contracts.

The group of employers most heavily represented in the anti-union category are those found among the Foodstuffs organisation. There are, for example, no union-negotiated contracts with any owner-operated Foodstuffs store in the South Island, although in the North Island, some 10 union-negotiated collective contracts are spread over 13 sites. Union sources claim some 10 union-negotiated collective contracts are spread over 13 sites. Union sources claim
that the Foodstuffs philosophy is biased to workplace bargaining and to individual contracts; also that individual owner-operators in this group who are prepared to negotiate are frequently pressured not do so by fellow operators.

\section{Internal labour market flexibility: forms and variations}

Despite these individual variations of style and practice the various contracts display distinct similarities in outcomes. Examples of these, noted in a range of collective and individual contracts currently in force in the industry, including examples from non-union contracts, are shown in Tables 3 to 7 inclusive.

Labour market flexibility has many classifications and can be applied both to external flexibility (within occupations or across the workforce as a whole) and to internal flexibility (within the enterprise). Both classifications encompass such aspects as wage levels (both (weractices and work patterns and generar arket Flexibility, 1986 and National Labour Consultative Council, Labour Market Flexibility in the Australian Setting, 1987 cited in Consultative Council, Labour
Rimmer and Zappala, 1988).

In this case the focus is on internal flexibility, in particular the forms of flexibility initiated through the restructuring of work practices and work patterns at the level of the workplace. For this res the proposed by Rimmer and Zappala For this National Economic Development Office, and they encompass the five main forms of National Economic Development
internal labour market flexibility.

The first of these, External Numerical Flexibility, refers to the ability of the employer to make short term adjustments in the number of employees to meet changes in patterns of consumer cons the thiming of work within the maling existing workforce. The third, Functional Flexibility, provides for "multi-skilling" and the avoidance of the necessity for hiring or firing by allocating labour to different tasks within
the workplace. The fourth, Wage Flexibility, permits variations to overtime and shift work arrangements and facilitates the linking of individual earnings to increased productivity by way of incentive schemes or performance-based pay. It also extends to the area of non-

wage labour costs. The final form, Procedural Flexibility, provides for the establish

\section{Flexibility and new contracts: summary and review}

The difficulty experienced in gathering the information set out in these tables, particularly The diffich comparative analysis. These tables therefore, together with Table 2, should be seen as comparative analysis. These tables therefore, together with Table 2 , should be seen as
illustrative illustrative rather than inclusive. Partly for this reason and partly for reasons of
confidentiality, the identification of specific enterprises or workplaces with specific provisions has been avoided.

The primary concern of the introduction of the forms of External Numerical Flexibility (Table 3) has been with the relaxation of previous provisions that constrained the utilisation 
of casual work to meet short-term demand. The concept of a "trial period" of employment and the provision allowing an offer of alternative employment to substitute for redundancy are essentially cost-avoidance measures. The former, of dubious legality and mainly confined to individual contracts, confers a limited right for dismissal without cause. Depending on how it is applied, this provision has the potential to become a backdoor to a casualised industry, or to lead to an improvement in the overall quality and training of staff. The last provision allows a greater discretion to rationalise, restructure or relocate an operation.

\section{Table 3: Examples of External Numerical Flexibility provisions} noted in a range of current collective and individual employment contracts in the retail food industry (as at March 1993)

\section{"Trial periods" of employment.}

"Temporary" contracts.

"Casual" engagements for periods of up to 14 days.

Employer entitled to allocate overtime to ensure an "adequate and balanced team".

Offer of employment in a subsidiary or associated company to constitute a legitimate alternative to redundancy.

The most significant variations to previous award conditions and those that affect the greatest number of workers are found in the forms of Internal Numerical Flexibility (Table 4). Their overall effect is to provide employers with a much improved flexibility in matching staff numbers to customer flow.

A consequence of these provisions appears to have been an increase in overall employment levels, largely by virtue of the addition of extra shifts to accommodate longer opening hours. On the other hand, the employer's increased discretion in determining the actual hours worked have also resulted in an increase in the ratio of part-time to full-time workers, with many former full-time positions increasingly reduced to part-time ones. The "proportions" clause, that could have limited this practice by setting a ratio of junior workers to seniors, is still included in some union-negotiated contracts. However its provisions are invariably less stringent than under the former award.

Possibly the most important provisions for increasing flexibility are those that allow the employer a discretionary right to reduce or vary the working hours of any staff member. Although subject to quite specific criteria, these give employers the opportunity to rotate part-time workers in such a way as to significantly reduce the incidence of penal rates for full-time staff. ${ }^{4}$ This facilitates the employment of supplementary part-time staff at peak periods or on late nights and weekends.

Table 4:

Examples of Internal Numerical Flexibility provisions

noted in a range of current collective and individual

employment contracts in the retail food industry (as at March 1993)

40 hour week spread over 7 days.

40 hour week to be worked on any 5 days.

40 hour week to be worked on any 4 days.

"Ordinary" hours of work permissible over any period between 6 a.m. and 9:30 p.m.

10 hour "ordinary hours" working day.

Variations to hours of work by mutual agreement, or at employer's discretion for "commercial reasons".

Variations to hours of work at employer's discretion.

Reduction in normal hours at employer's discretion for "genuine business needs".

Reduction in period of prior notice of requirement to work overtime.

Half-hour meal breaks.

Observance of specified public holidays on alternative dates, as nominated by employer.

Only 2 of any weekly days off need be taken consecutively.

Separate contracts and conditions for "managerial" staff.

4 On the basis of information obtained in interviews with employees of all the major groups, it can be concluded that paid overtime for full-time employees has virtually disappeared from the industry. 
Although there are no provisions in any union-negotiated contract that allow split shifts or on-call work, union sources claim they are aware such positions are being offered. They acknowledge that the accuracy of these claims and the extent of the practice are difficult to monitor as few complaints are received from the workers themselves. This they attribute to a number of factors, including lack of awareness of rights and entitlements, the opportunity of extra income or simply the desire for work and the fear of the loss of a job should employees complain.

The concepts of Functional Flexibility (Table 5) and multi-skilling are not new to the industry, particularly in the case of the smaller stores. Even in the larger operations, the interchange of staff between checkout and delicatessen and the use of stand-by checkout operators to carry out shelf-filling during slack periods are standard practices. What is new is the extension of this form of flexibility to the areas of demarcation and job classification. The inclusion of all employees under a single contract brings all staff including bakers, butchers and clerical staff under the same contract umbrella, facilitating the introduction of broad-band job classifications and performance based rates of pay.

\section{Table 5: Examples of Functional Flexibility provisions noted in a range of current collective and individual employment} contracts in the retail food industry (as at March 1993)

\section{No job demarcations.}

Allocation of employees to any task or position within the establishment, as required by employer.

Limited range of job classifications.

No specific job classifications.

Employer able to incorporate "new categories" of worker into contract.

Single document covering all employees.
In the area of Wage Flexibility (Table 6), the greatest emphasis has been placed on cost saving through the extension of employer control over pay structures. The range of provisions noted includes a performance based pay scale, a narrowing of the range of job classifications, the substitution of fixed allowances for penal rates and an overall reduction in levels of penal rates themselves. Also included are more stringent criteria for payments of allowances and sick pay. Non-wage provisions for easing administrative costs include the "rounding-off" of wages, the ability to vary the pay day and payment by direct credit as a condition of employment.

Table 6:

Examples of Wage Flexibility provisions noted in a range of current collective and individual employment contracts in the retail industry (as at March 1993)

Performance-based pay scales.

Standard hourly rate up to 10 hours per day on any day of the week. Standard hourly rate for 40 hours work over a seven day period.

Reduced overtime rates.

No penalty rates.

Penalty rates only applicable for existing staff.

Penalty rates replaced by fixed or variable allowances (existing staff only)

Reduction in allowances.

Late night allowances to apply only to existing staff.

Stringent requirements for prompt notification of sick-leave absences.

Changes to basis for payment of meal allowances.

No meal allowances.

Reduction in pay permissible as a disciplinary measure.

"Rounding-off" of wage payments.

Payment of wages by direct credit unless by agreement.

Variations to pay day allowable by mutual agreement. 
Finally, although provisions for Procedural Flexibility (Table 7) are not extensive, they indicate a trend towards the replacement of external negotiation by in-house consultation in seeking to vary the contract. This factor assumes greater significance when set alongside the possibility (noted above) of the development of company based structures of collective bargaining.

Table 7: Examples of Procedural Flexibility provisions noted in a range of current collective and individual employment contracts in the retail food industry (As at March 1993)

Consultation provisions for discussion on a range of employment issues - by mutual agreement between employer and union.

"Enabling provision" for introduction of productivity agreements.

Variation of contract during term in an individual establishment allowable by agreement between employer and workers, subject to prior consultation with bargaining agent.

Variations in method of paying wages, by individual agreement between employer and employee.

Automatic dismissal if worker exceeds specified period of sick leave.

Stringent codes of conduct and disciplinary procedures.

\section{Summary}

While not all-embracing, this data suggests that the achievement of optimum results is generally the product of a combination of numerical flexibility - both external and internal - and functional flexibility. The evidence suggests that, through combinations of these various arrangements, employers have made considerable across the board gains in internal various arrangements, emp
labour market flexibilities.

In terms of the general level of wages, the combination of extended opening hours and the reduction in the quantum and application of penal rates has resulted in an increase in the overall number of employees. However this has been substantially confined to the part-time work and at lower overall rates of pay. The impact on earnings appears to have been significant. Overall it has been uneven, but union sources estimate that the effective loss of penal rates for many workers, coupled with the introduction of performance-based pay scales, has resulted in a drop of as much as one-third in normal weekly earnings. They also estimate that changes to sick leave and annual leave have reduced the monetary value of those entitlements by as much as 50 percent and 25 percent respectively. If the cost savings to the employers reflect the extent of these wage reductions it can be assumed they have made substantial gains in this area.

In the elements of work patterns and work practices, the immediate and most obvious consequence of these cost savings and flexibility provisions can be seen in the extension of opening hours, with seven day opening now commonplace throughout the industry. Countdown stores in Christchurch and in parts of the Wellington area have further extended their opening hours until midnight on five nights of the week, largely staffed by workers employed on a separate 9 p.m. to midnight shift. At the time of writing, this practice does not appear to have been followed generally by their competitors. Nevertheless it is a clear illustration how the pursuit of competitive edge goes hand-in-hand with the pursuit of flexibility in this industry.

In the broader sense, the most significant gain for employers in this industry may well be in the greater freedom they have gained in the bargaining process. Paradoxically, it is not the internationally owned firms that have taken advantage of the deregulated environment to reject union involvement, but the local ones, notably the Foodstuffs and the former GUS (now FAL) groups. This highlights the potential significance of organisational and ownership forms as a major determinant of future labour relations practices.

\section{Future bargaining trends}

This is an industry in which the setting of wages and conditions has traditionally been dependent on institutionalised bargaining, rather than on the power of organised labour (Hince, 1991). The apparent ease with which these contract variations have been introduced, coupled with the strong anti-union attitude of a major section of the industry's employers, suggests the future role of organised labour may be problematic. Indeed there is some evidence to suggest that the union's present involvement in collective agreements has been the consequence of employer policy decisions, rather than the result of the socalled "countervailing power" of an organised workforce. This invites the question, will organised labour continue to have a role in the setting of conditions of employment in this industry; and if so, who will organise it and to what purpose?

Traditional union recruitment problems in the retail food industry have been compounded by the introduction of the Employment Contracts Act, coupled with the proliferation of new outlets and a massive influx of casual staff. Making contact with potential members has become a major problem for union representatives, particularly where there is no union contract and the right of entry has been compromised. Some views to the contrary notwithstanding (Boxall and Haynes, 1992), union experience seems to suggest that the potentially adverse consequences of "free riding" have not yet been sufficiently recognised 
contract is in place, many new staff feel no compulsion or necessity to join the union. In one such case it was said that only around one third of the total 120 staff were union members.

These current difficulties come on top of the residual effects on existing membership figures of several years of recession and high unemployment. Accurate membership figures were not readily available and estimates varied from one region to the next. However there is little doubt that there have been significant falls in membership numbers, possibly by as much as 15 percent to 30 percent.

Moreover, current trends in retailing suggest the possibility of a further fragmentation of union membership. There is some evidence of a growing divergence between the development of food retailing and ordinary retailing, with the latter seeking to re-establish itself through the development of small business franchising on the one hand and the introduction of the hyper-store on the other. Given the growth of part-time work, combined with enterprise bargaining, this divergence of interests may well produce a further segmentation of existing union organisation, with the substitution of notions of individualadvantage interest for those of collective interest.

The union response has not been without interest or success. Strategies such as the recently instituted American-style "Buy Union" campaign, which encourages the public to buy only at stores with union contracts, and the use of "awareness" pickets at non-union sites at Glen Innes, Island Bay, and Kaikohe, mark an interesting new development in industrial relations in the retail food industry. In a significant reversal of traditional practice, the picketing of non-union sites is not generally being undertaken by workers on-site, engaged in furtherance of their own claims, but by other workers already receiving the benefit of union contracts and concerned to protect terms and conditions in the industry.

Nevertheless these actions appear to be only an attempt at "holding the line" and this may well encourage further employer attempts to marginalise the union. If these occur and are successful, we can expect an increasing diversity both of bargaining styles and of outcomes.

\section{Conclusion}

With the entry of international capital, food retailing in New Zealand has become a large scale business. In the transition, the industry has assumed those characteristics which contemporary research into the structures of food retailing firms in Australia and the United Kingdom has identified as typical of the industry world-wide (Hammond, 1992; Marchington and Parker, 1990; Marchington and Harrison, 1991; Lewis and Thomas, 1990)

These characteristics - a tendency to integration and concentration, together with an increasingly juvenile and female workforce and a relatively low level of union organisation or participation (Marchington and Parker, 1990), have combined with major changes in the economic and legislative environment to exacerbate the industry's inherent tendency to competition. This in turn has placed a high priority on the search for greater flexibility in the structures of its internal labour market.
The momentum of progress in this search has been patchy, sometimes impelled and at other times impeded by the economic and legislative environment at both macro and micro levels. The most significant factor in releasing the "roadblock" of legislative constraint has been the advent of the Employment Contracts Act and the abandonment of the national been system. The diversity of bargaining arrangements and outcomes that have emerged wake has revealed a significant weakness in the ability of intitur ore wake has revealed a significant weakness in the ability of institutionally organised labour to deal with this new industrial environment. This suggests that the appearance of contrasting patterns and models of industrial relations practices within the same industry may become as normal a feature of industrial relations in a deregulated labour market in New Zealand as it appears to be in the United Kingdom (Marchington, 1992).

\section{References}

Unpublished Sources: Series of interviews with employees and managerial staff of the four major supermarket groups, conducted between January 1991 and January 1993 . In deference to the confidentiality requested by the interviewees, exact sources are not identified.

Asian Company Handbook (1990), Tokyo, Toyo Keizai Inc.

Barner, John L. (1992), Financing Supermarkets, Shopping Centre News, 10(5): 11-13.

Birch, Hon. W.F. (1991), Address to the Napier Chamber of Commerce and Community Leaders, 20 September 1991

Boxall, Peter and Haynes, Peter (1992), Unions and Non-Union Bargaining Agents under the Employment Contracts Act 1991: an Assessment after 12 Months, New Zealand Journal of Industrial Relations, 17(2): 223-232.

Boxall, Peter (1993), Management Strategy and the Employment Contracts Act 1991. In Harbridge, R. (ed.) Employment Contracts: New Zealand Experiences, Wellington, Victoria University Press.

Brosnan, P. (1991), Labour Market Flexibility and the Quality of Work: a Case Study of the Retail Industry, New Zealand Journal of Industrial Relations, 16(1): 13-36.

Chapple, G. (1988), Supermarket Wars, New Zealand Listener, 122(2538): 27-29.

Child, John (1969), The Business Enterprise in Modern Industrial Society, London, CollierMcMillan.

Department of Labour (1992), Contract, The Report on Current Industrial Relations in New Zealand, (July) 3 .

Department of Labour (1992), Contract, The Report on Current Industrial Relations in New Zealand, (October) 4. 
Department of Labour (1992), Contract, The Report on Current Industrial Relations in New Zealand, (November) Special Edition (November).

Ducatel, Ken and Blomley, Nicholas (1990), Rethinking Retail Capital, International Journal of Urban and Regional Research, 14(2): 207-227.

Enderwick, Peter (1992), Workplace Reform and International Competitiveness: the Case of New Zealand, New Zealand Journal of Industrial Relations, 17(2): 185-206.

Hammond, Suzanne (1992), Labour Market Deregulation - A Comparative Study of Retail Industry Workplaces, The Journal of Industrial Relations, 34(1): 31-47.

Hammond, Suzanne and Harbridge, Raymond (1993), The Impact of the Employment Contracts Act on Women at Work. Paper presented to the Women at Work: issues for the 1990s seminar at the Industrial Relations Centre, Victoria University of Wellington, 12 February 1993.

Harbridge, Raymond (1992), Emerging Trends in Collective Bargaining. Paper presented to Union Education Trust seminar, Christchurch, 11 September 1992.

Harbridge, Raymond (1993), Bargaining and the Employment Contracts Act: an overview. In Harbridge, R.(ed), Employment Contracts: New Zealand Experiences, Wellington, Victoria University Press.

Hardy, Cynthia (1985), Managing Organisational Closure, Great Britain, Gower Publishing Company.

Herbert, Patricia (1991), Employers See Defects in Labour Bill, The Press, 14 April, Christchurch.

Hince, Kevin (1991), Is Euro-American Union Theory Universally Applicable? An Australasian Perspective. Working Paper 4/91 ISSN 0113-1788, Wellington, Industrial Relations Centre, Victoria University.

Hince, Kevin with Taylor, Kerry; Peace, Jacqui and Biggs, Michael (1990), Opening Hours History of the Wellington Shop Employees Union, Wellington, Industrial Relations Centre, Victoria University.

Lewis, Pam and Thomas, Howard (1990), The Linkage Between Strategy, Strategic Groups, and Performance in the UK Retail Grocery Industry, Strategic Management Journal, 11: $385-397$.

Littler, Craig (1990), The Labour Process Debate: A Theoretical Review 1974-88. In David Knights and Hugh Willmott (eds), Labour Process Theory, London, MacMillan Press.

Marchington, Mick and Harrison, Eric (1991), Customers, Competitors and Choice: Employee Relations in Food Retailing. Industrial Relations Journal, 22(4): 286-299.
Marchington, Mick and Parker, Philip (1990), Changing Patterns of Employee Relations, London, Harvester Wheatsheaf.

McAndrew, Ian and Hursthouse, Paul (1991), Reforming Labour Relations: What Southern Employers Say, New Zealand Journal of Industrial Relations, 16(1): 1-11.

National Distribution Union (1992), Under Contract: A Brief Report on the Use of the Employment Contracts Act in the Retail Sector.

Northern Distribution Workers Union (1992), Don't Shop at Glen Innes Pak'n Save. (Series of information leaflets distributed during picket).

Overseas Investment Commission (1992), Decision Sheets Pages 13 and 26 July 1990 and 75-78 July 1992, Wellington, Overseas Investment Commission.

Rimmer, M. and Zappala, J. (1986), Labour Market Flexibility and the 2nd Tier, Australian Bulletin of Labour, 14(4): 564

Ryan, Rose (1992), Flexibility in New Zealand Workplaces: A Study of Northern Employers, New Zealand Journal of Industrial Relations, 17(2): 129-147.

Second New Zealand Sweating Commission (1990), Report of the Second New Zealand Sweating Commission, 25 February.

Supermarketing, New Zealand's Premier Grocery Magazine (1991-1993).

The Merchant, official journal of the Retail and Wholesale Merchants Association of New Zealand (1990-1993).

Williams, Alan (1993), Report Backs Progressive Move, The Press, 26 September, Christchurch. 